\title{
A Theory of Profit Sharing Ratio under Adverse Selection: The Case of Islamic Venture Capital
}

\author{
KAOUTHER JOUABER \\ DRM-Finance, Université Paris-Dauphine \\ Place du Maréchal de Lattre de Tassigny \\ 75775 PARIS Cedex 16 \\ E-mail: kaouther.jouaber@dauphine.fr \\ MERYEM MEHRI \\ DRM-Finance, Université Paris-Dauphine \\ Place du Maréchal de Lattre de Tassigny \\ 75775 PARIS Cedex 16 \\ E-mail: meryem.mehri@dauphine.fr
}

This version

April 28, 2012

\begin{abstract}
This paper presents a theory for Islamic venture capital namely 'Mudharabah' contract under adverse selection problem. In order to avoid selecting a low type entrepreneur for a given good project, the framework defines the profit sharing ratio (PSR) as a screening device. We then develop a Profit Sharing Ratio model for Islamic venture capital under adverse selection. We find the optimal PSR as function of the respective risk aversion degree of both the entrepreneur and the IVC (Islamic venture capitalist). Their risk aversion degrees influence their decisions to fix the PSR during the negotiation stage. We show that the high type entrepreneur will tolerate to the IVC a PSR higher than the PSR accepted by the low type. In the negotiation stage, whatever the entrepreneur type, the higher the management fee and the higher the PSR tolerated to the IVC.
\end{abstract}

Key words: Islamic Venture Capital, Mudharabah, Profit Sharing Ratio, Adverse Selection, Risk Aversion degree.

JEL codes: D82, G21, G23, G24. 


\section{Introduction}

The two primary alternative modes to conventional financing are Profit-and-Loss Sharing (PLS) contracts, namely Mudharabah (Islamic venture capital) and Musharakah (Islamic joint venture), which dominate the theoretical literature on Islamic finance. The development of modern Islamic venture capital began with evolution of modern Islamic finance, which was emerged with the creation of Islamic banks in the early 1960s. However, venture capital is seen as one of the capital market activity. In this regard, the period of 1990s to 2000s considered as a golden era for emergence of Islamic capital market, which comes into being as a result of inactive of funds generated in Islamic banks and Takaful companies on account of limitation in investment opportunities (Securities Commission Malaysia, 2009).

Islamic venture capital has the same purpose as conventional venture capital except that it operates in consistency with the percepts of Islamic Law. The Islamic Law allows the sale of tangible products that are excluded from sectors deemed illegal (such as sales of alcohol or pork). It also prohibits uncertainty, speculation, and interest rate that is considered as a surplus on the capital without any effort. Islamic venture capital is not a simple Islamic contract that emanates its rules from Islamic Law, but it is based on the net income sharing principle of the Reward-Sharing Theory (Sarker, 1999). "The notion of profit-sharing pervaded even conventional business organizations let alone Islamic finance” (Hasan, 2008). Nevertheless, there are slight differences between Islamic and classical venture capital. The most important difference lies in the profit sharing in a predetermined ratio that will be negotiated between the IVC and entrepreneur whereas the CVC receives a carried interest (around 20\%). Lerner (1999) reports that $81 \%$ of their sample VC funds use a carry level between $20 \%$ and $21 \%$. The second difference is that the CVC can be an advisor and is involved in the management of the project while IVC is preventing from performing the project. 
In this paper, we focus on Islamic Venture Capital (Mudarabah contract), in which the Islamic bank takes the role of an Islamic venture capitalist (IVC ${ }^{1}$ who provides the capital, bears the losses, and shares the profit with the entrepreneur in a pre agreed profit sharing ratio (PSR). This concept was developed and used by Islamic Banking around the world and is a reason among others that has attracted Islamic investors (Abdul-Razak and Ismail, 2009).

Nevertheless, the different Islamic banks tend to be reluctant to resort to Islamic venture capital and Islamic Joint Venture (Galloux, 1999). The fixed return financial tools such as Murabaha and Islamic Leasing Ijarah become dominant in the current Islamic financial system (Khan and Mirakhor, 1987; Al-Jarhi, 2001; Bashir, 2001; Tag El-Din, 2008). According to the International Association of Islamic Banks, the PLS contracts have covered less than $20 \%$ of investments by Islamic banks worldwide (Farooq, 2007). Similarly, the Islamic Development Bank (IDB) has not used the PLS contracts in its financial transactions except in few small projects (Dar and Presley, 2000).

The failure of the application of the PLS contracts, is likely due to the confrontation of Islamic banks to serious agency problems such as moral hazard and adverse selection (Kahan, 1985; Haque and Mirakhor, 1986; Bashir, 1996; Bashir, 2001; Al-Jarhi, 2004). Actually, these agency problems arise from information asymmetry between the partners in the PLS contract and give rise to high monitoring and screening cost (Bacha, 1997). In such a case, the bank would face difficulties resulting from the limited available information about both the quality of the E (Mills and Presley, 1998) and the exact rate of return on her investment capital (Williamson, 1986).

However, the present paper studies the adverse selection problem in the case of IVC. Our choice is motivated by three reasons. First, The Classic Venture Capital becomes a real lever

\footnotetext{
${ }^{1}$ Throughout this paper, we note Islamic Venture Capital as IVC. This IVC could be an Islamic Bank that offers Mudharabah contract or a private Islamic Venture Capitalist such as Dubai-based Injazat Capital Limited and Venture Capital Bank BSC which are the largest Islamic venture capital funds in the Middle East.
} 
for economic and financial dynamism and encounters a great success in the international markets like in the United States (Chemla and De Bettignies, 2006; Casmatta, 2003).Yet, it has the same principle as Islamic venture capital and was used by Arab traders even before Islam (Abdul-Mutalip, 2000). Second, despite the advantages of Islamic venture capital as a funding mode, there is little offered by Islamic banks, preferring the short-term financing (e.g., Murabaha) to maximize the fixed return on their loan portfolio with activities that relate quickly. Third, the adverse selection problem under Islamic venture capital is likely to be more important than in Musharakah and conventional venture capital ${ }^{2}$ since according to the Islamic Law, the entrepreneur does not contribute to investment capital. In the same time the IVC is prevented from performing the project and bears all the losses if the project defaults. Consequently, the entrepreneur cannot be controlled and has an incentive to behave in her own interest. Chapra and Khan (2000), consider that Islamic venture capital is the most risky mode in Islamic finance. In addition, previous to financing and investment stage, the IVC performs a primordial phase to select the high type entrepreneur to run the good project. She will attempt to detect the feasibility of the project, the structure of the relevant business line, and the entrepreneur type. Particularly, she will come up against difficulties in defining the entrepreneur type, each prospective applicant to a sharing agreement claiming to be of high type. In a general case, the imperfect information about the entrepreneur type may increase the risk taken by the borrower or affect the performance (Berger et al., 2010).This difficulty explains the origin of adverse selection problem especially for Islamic venture capital, in which the investment funds are coming from external sources (Mills and Presley, 1998) and where the IVC cannot intervene in the decision making process of the entrepreneur.

We develop a theoretical model considering the risk aversion of both IVC and entrepreneur. In this framework, we try to answer the following questions: What are the respective gain

\footnotetext{
${ }^{2}$ In the case of Musharakah and classical Venture Capital, the venture capitalist can run the project with the entrepreneur. Then, we consider that an agency problem (either adverse selection or moral hazard) is less likely to affect the income of the project than in the case of IVC.
} 
profiles of the IVC and the entrepreneur? How the adverse selection risk could affect the setting of the PSR and the income of IVC? Which optimal PSR would satisfy both parties and avoid the adverse selection problem?

This paper is organized as follows. We develop the literature review in section II. Section III presents a Profit Sharing Ratio model and the assumptions. The optimal contract is solved in Section IV where we demonstrate how IVC and entrepreneur negotiate and fix the optimal PSR that avoid adverse selection problem. Section V discusses the optimal PSR as function of risk aversion degree of the IVC and the entrepreneur by using Edgworth Box. In this section we discuss the convergence of the PSR in the negotiation stage. Section VI presents the simulation results that confirm our theoretical intuition. The last section concludes the paper. All proofs are made in Apprendix.

\section{Literature Review}

Few models have been developed to solve adverse selection problem and information asymmetry in Islamic venture capital case. We present the best known and most influential models. Asymmetry in the distribution of information about the entrepreneur type associated with a divergence with interests give rise to agency problems (Berle and Means, 1932). These agency problems are also due to the inability of the bank to accurately detect the return rate on her investment capital (Williamson, 1986). In addition, the entrepreneur has always privileged information about her personal activities (Al-Jarhi and Iqbal, 2001). Either she overestimates the probability of success that cannot be reported to the bank (Manova and al., 2001) in order to induce the latter to finance the project, or ex-ante reports a high expected profit to induce the IVC to choose a lower PSR (Nienhaus, 1983). In the present paper, we assume that the IVC can detect the quality of project by screening. Then, the information asymmetry between IVC and entrepreneur is only about the entrepreneur type. 
As part of solving the adverse selection problem for Islamic venture capital contract, some researchers argue that the profit share in a predetermined ratio leads the entrepreneur to behave honestly (Khan, 1985) because their income depends on their operations (Sarker, 1989; Kazarian, 1991). To decrease agency problems, Sarker (1989) proposes incentives for honesty like providing stake in the ownership, linking transfer of ownership through granting bonus shares on the performances, build reserve scheme to induce to hold company shares and provision for profit-related pay linking with the declaration of profits. These proposals focus on incenting rather than preventing the agency problem and fail to solve adverse selection problem that needs a preventive measure. Bacha (1997) suggests an alternative financial arrangement under Islamic venture capital contract. Using the principles of mezzanine and vertical-strip financing, currently in venture capital and other high risk financing like Leveraged Buyouts (LBOs), it is shown that a more equitable distribution of profits and risk can be achieved. This suggestion implies that the entrepreneur proceeds to a reimbursement of VC in form of part of her equity in the event of certain profits. This solution reduces the agency problems and the downside risk of return faced by the IVC, but it does not eliminate all such risk. Hence, both entrepreneur and IVC will be required to be responsible and cautious in undertaking new projects. This solution is possible in the case of Islamic venture capital contract when the entrepreneur is a corporation having her own paid up capital. The proposal by Bacha (1997) can be criticized because it does not prevent adverse selection problem, but it tries to solve it after it has occurred. Another possible critic of this proposal is that the market value of shares of the entrepreneur could be weak or zero if the project fails. Karim (2000) argues that the contribution of entrepreneur to the capital and the use of collateral could solve the adverse selection problem. We argue that this solution is not possible in the case of Islamic venture capital contract, because according to Islamic Law the IVC cannot require a guarantee of profit (AAOIFI, 2003). There is only collateral of breach or 
negligence of any term of the contract on the part of entrepreneur. In addition, referring to the literature about conventional financing under adverse selection problem, the collateral remains a very limited governance mechanism to avoid this agency problem (Manove and Padilla, 1999).

Shaikh (2011) argues that the problem is in the disparity in payoffs if the project defaults. In Islamic venture capital contract, to be willing to take higher risk, the IVC would demand higher outcomes reflected in demand for higher PSR. Nevertheless, with higher PSR, the entrepreneur's motivation and incentive decrease especially if the entrepreneur requires bearing no financial losses and already having means of sustenance with another business line. In the present paper, we demonstrate that, under adverse selection about the entrepreneur type, PSR is considered as a screening device in the negotiation stage and a high PSR depending on the risk aversion of the entrepreneur and the risk aversion of the IVC, can be a signal of the selection of high type entrepreneur.

To summarize, this stage of selection of the high type entrepreneur is a complex phase that requires a high level of screening of the entrepreneur type and the financial and personal features of the project (activities, products, sector, etc.). The Islamic venture capital contract has, additionally, other features that could prevent entrepreneur with low quality of management. We prove that the degree of PSR may lead the IVC to detect the true type of the entrepreneur in the negotiation stage. In this case it may happen that a good project of a high type entrepreneur will be not financed by Islamic venture capital contract because the negotiated PSR $\Omega$ is very high or the conditions of the contracts are too strict. This stage is very tricky for the IVC.

This paper attempts to identify an optimal PSR that could avoid the agency problem between partners. Several researchers have tried to develop an optimal PSR under symmetric information (Hasan, 1985; Haque and Mirakhor, 1987; Bashir, 2001; Ahmed, 2002; Tag El- 
Din, 2008; Sugema, Bakhtiar and Effendi, 2010). The adverse selection problem is however not sufficiently addressed in the literature.

\section{The Model}

In this section we describe our Profit Sharing Model under adverse selection. To simplify our reasoning we begin with information symmetry about the type of the entrepreneur.

\section{A. The benchmark case without adverse selection}

As a benchmark case with information symmetry for the entrepreneurs type (i.e. when their type is observable by the IVC), consider entrepreneurs endowed with innovative investment projects that require an initial investment amount $I$. Assume that the credit market populated by $n \geq 2$ IVCs and there are several other possible financing modes. Only entrepreneurs who have not an initial capital to finance their own projects (i.e. projects that meet the requirements of the Islamic Law) will apply for an Islamic venture capital contract. The IVC provides the whole initial investment $I$ and the entrepreneurs are endowed with technical skills and management expertise that constitutes their human capital (their contribution) to run projects. To keep things simple, assume that at $t_{0}$ (period of financing) there are projects with fixed size (that are normalized to 1 ). The projects are risky and generate a verifiable expected profit $\tilde{P}$. Suppose that projects come in two qualities, good with positive expected present value or bad with negative expected present value. The applicants know the probability distribution of choosing a good project, but they cannot observe actual project quality. The IVC can detect the true quality of the project by screening. The act of screening is assumed to be observable and contractible, so this screening stage is also a service to the entrepreneurs ${ }^{3}$ who must bear a proportion of the screening cost as application fee. After screening, the IVC accepts to finance the project if and only if it turns out to be a good one. We mean that in

\footnotetext{
${ }^{3}$ In this model, we assume that the true quality of the project is observable by the entrepreneurs and the IVC, because the project is screened. We assume that there is no information asymmetry for the quality of the project because naturally a small firm cannot prove the true quality of her project (Lean and Tucker, 2001), so the project must be screened by the IVC and according to Islamic Law, the two parties must know all the features of the project in a clear manner before signing the Islamic venture capital contract.
} 
equilibrium IVC would screen the quality of the project and funds only entrepreneur with good project. The IVC can request a guarantee of honesty $C$ to entrepreneur ${ }^{4}$. Entrepreneur and IVC are risk averse. At $t_{0}$ the IVC proposes a PSR $\Omega^{\prime}$ that is likely to be negotiated ${ }^{5}$ with the entrepreneur. The final negotiated PSR $\Omega$ may be different from (or equal to) the initially proposed PSR $\Omega^{\prime}$ and depends on the bargaining power of the entrepreneur. At the liquidation time $t_{0}+1$, if the project succeeds $P \succ 0$ i.e. $R \succ I$ (with $\mathrm{R}$ is the project value i.e. equal to the sum of $I$ and $P$ ), the IVC and the entrepreneur receive respectively their profit shares $\Omega \widetilde{P}_{t_{0}+1}$ and $(1-\Omega) \tilde{P}_{t_{0}+1}$. Denote $\tilde{\Pi}_{t_{0}+1}\left(\tilde{P}_{t_{0}+1}, \Omega\right)=\Omega \tilde{P}_{t_{0}+1}+I$ the expected payoff to IVC and $\tilde{\Phi}_{t_{0}+1}\left(\tilde{P}_{t_{0}+1}\right)=(1-\Omega) \tilde{P}_{t_{0}+1}+g$ the expected payoff to entrepreneur at the liquidation time $t_{0}+1$ with $g$ is the management fee. If the project defaults $P \prec 0$, the IVC bears the losses and the entrepreneur loses only her effort of management.

\section{Insert Figure 1 here}

Figure 1 plots the payoffs to the IVC at liquidation time. In the first graph, the payoff is plotted as function of $\widetilde{P}_{t_{0}+1}$ and in the second it is illustrated as function of $\widetilde{R}_{t_{0}+1}$. Following this figure, we note that the gain profile of the IVC is similar to the gain profile of the seller of put option. Then, we note the expected payoff to the IVC as follow

$$
\tilde{\Pi}_{t_{0}+1}=\operatorname{Max}\left[-\tilde{P}_{t_{0}+1} ; \Omega \tilde{P}_{t_{0}+1}\right]+I
$$

As illustrated, beyond the point $\widetilde{P}_{t_{0}+1}=0$, the IVC receives $\Omega \widetilde{P}_{t_{0}+1}$ and recovers her invested capital $I$. If the project defaults the IVC bears the losses $\tilde{P}_{t_{0}+1} \prec 0\left(R_{t_{0}+1} \prec I\right)$ and the losses will be deduced from the capital $I$.

\footnotetext{
${ }^{4}$ The guarantee of honesty and not of capital may be a written document such as attestations, personal guarantees, pledges, checks and promissory notes. The Islamic Law prohibits to seek the guarantee in the trust contract of IVC. It is not possible to require from entrepreneur or one of the partners in the contract to guarantee the capital or the profit. Therefore, it is not permissible for Islamic venture capital contract to be operated as a guarantee contract. A contract of guarantee can be established. 'This is circumscribed with a condition that the capital provider will not enforce these guarantees except in cases of misconduct, negligence or breach of contract on the part of manager' (AAOIFI, 2003). For this reason we do not consider the guarantee as an important and determinant parameter in the contract.

${ }^{5}$ According to the Islamic Law, the PSR must be negotiated between the entrepreneur and the IVC (AAOIFI, 2003).
} 


\section{Insert Figure 2 here}

Figure 2 plots the payoff to the entrepreneur as function of $P$ and then as function of project value $R$. Following this figure, we find that the gain profile of the entrepreneur is similar to the gain profile of the buyer of call option. Then, the expected payoff to the entrepreneur is as follow

$$
\widetilde{\Phi}_{t_{0}+1}=\operatorname{Max}\left[0 ;(1-\Omega) \tilde{P}_{t_{0}+1}\right]+g
$$

As illustrated in the graphs (2.1) and (2.2), when the project net income is zero or negative ( $\tilde{R}_{t_{0}+1}$ is below $I$ ), the entrepreneur loses only her effort and keeps her management fees. If the project generates positive profit, there is profit sharing.

In the benchmark case with information symmetry, the value of the payoff to the IVC $\tilde{\Pi}_{t_{0}+1}(\Omega)$ is an increasing function of the negotiated PSR. This result can be implemented in a simple way. A good project which is performed by a high-type entrepreneur (who has high skills and the ability to run the project) generates naturally a positive return. Then, the IVC will receive a positive payoff regardless the PSR level. In particular, a high PSR will not affect negatively the project return. Therefore, the payoff to the IVC remains positive whatever the PSR is (high or low) because the entrepreneur has high skills to perform the project (her type is perfectly known by the IVC) and there is no information asymmetry. This contrasts sharply with the next conclusions derived under adverse selection.

\section{B.The effect of adverse selection}

We now argue that with an additional dimension of incomplete information about the type of the entrepreneur, the Islamic venture capital contract may turn out to be inefficient. Consider the above scenario but now with two types of applicants: a high-type entrepreneur with a high level of management (has high skills to run the project) $m_{H}$, and a low-type entrepreneur with 
a low level of management (does not have enough skills to run the project) $m_{L}$. Assume that the entrepreneur who applies for the Islamic venture capital contract knows her own type, but the IVC cannot observe applicant true type. In any pooling equilibrium in which the project is screened, only applicant with good project will have her application approved.

Assume that the expected profit of the project depends on the entrepreneur type. Denote $p_{H+}$ the probability that the high-type entrepreneur $m_{H}$ performs the good project which would generate a positive expected profit $\tilde{P}_{H} \geq 0\left(\tilde{R}_{H} \geq I\right), p_{L+}$ the probability that the low-type entrepreneur $m_{L}$ performs the good project which would generate a positive expected profit $\tilde{P}_{L+} \geq 0 \quad\left(\tilde{R}_{L+} \geq I\right)$, and $p_{L-}$ the probability that the low-type entrepreneur $m_{L}$ performs the good project which would default with losses equal to $\tilde{P}_{L^{-}} \leq 0\left(\tilde{R}_{L^{-}} \leq I\right)$.

Our argument is that when the low-type entrepreneur runs the good project, the project can achieve a positive expected profit $\widetilde{P}_{L^{+}}$with $0 \leq \widetilde{P}_{L+} \leq \widetilde{P}_{H}$ or a negative expected profit $\widetilde{P}_{L-} \leq 0$. But if the high-type entrepreneur $m_{H}$ runs the good project the profit cannot fail except the case when the losses are due to the state of the nature.

If the project defaults, the IVC bears all losses $\tilde{P}_{L^{-}} \leq 0$ and cannot recover all her initial investment $I$. The entrepreneur keeps her management fee $g$ whatever the project performance is. The IVC expected payoff will be $p_{L^{-}} \widetilde{P}_{L^{-}}$or, in the case of negligence or contract breach, $p_{L^{-}}\left(\tilde{P}_{L-}+C\right)$. If the project succeeds, the IVC profit share is $\Omega \tilde{P}_{i}$ and the entrepreneur profit share is $(1-\Omega) \tilde{P}_{i}$, with $\tilde{P}_{i} \geq 0$ and $i$ being $L^{+}$or $H$ (with $\tilde{P}_{H} \succ \widetilde{P}_{L^{+}}$). Let $p_{i}$ be $p_{H}$ or $p_{L+}$ with $p_{H} \succ p_{L^{+}}$.

Denote $\tilde{\Pi}_{t_{0}+1}\left(P_{i}, \Omega\right)$ the IVC expected payoff under adverse selection problem at the liquidation time $t_{0}+1$, 


$$
\tilde{\Pi}_{t_{0}+1}=\sum_{i} p_{i}\left(\Omega \tilde{P}_{i}+I\right)+p_{L^{-}}\left(\tilde{P}_{L^{-}}\right)
$$

If there is no negligence or breach of Islamic venture capital contract ${ }^{6}$, and

$$
\tilde{\Pi}_{t_{0}+1}=\sum_{i} p_{i}\left(\Omega \tilde{P}_{i}+I\right)+p_{L-}\left(\tilde{P}_{L^{-}}+C\right)
$$

if there is negligence or breach of Islamic venture capital contract.

Under adverse selection, the entrepreneur payoff will be zero if the project defaults. In the extreme case of negligence or breach on the part of the entrepreneur, the entrepreneur may not loss higher than the amount of collateral $C$. If the net profit of the project is positive with a probability $p_{i}$, she will receive her expected profit share and management fee $g$. Denote $\widetilde{\Phi}_{t_{0}+1}\left(P_{i}, \Omega\right)$ the entrepreneur payoff under adverse selection problem at the liquidation time $t_{0}+1$

$$
\tilde{\Phi}_{t_{0}+1}=\sum_{i}\left(p_{i}(1-\Omega) \tilde{P}_{i}+g\right)
$$

if there is no negligence or breach of Islamic venture capital contract, and

$$
\tilde{\Phi}_{t_{0}+1}=\sum_{i}\left(p_{i}(1-\Omega) \tilde{P}_{i}+g\right)+p_{L-}(g-C)
$$

if there is negligence or breach of Islamic venture capital contract.

\section{Optimal profit sharing ratio}

We proceed to find the equilibrium where entrepreneur is an agent acting in such a way as to maximize the IVC expected utility (as principal expected utility). Our aim is to identify the relation between the PSR and the occurrence of adverse selection problem.

\footnotetext{
${ }^{6}$ We use for the remainder of the paper only the entrepreneur wealth and the IVC wealth in the general case when there is not negligence or breach on the part of the entrepreneur because the collateral does not guarantee the profit. We assume in our model that the entrepreneur is honest.
} 
The timing of the game under information asymmetry is as follows

At $t_{0}$ :

i. Nature chooses the type of the entrepreneur.

ii. The entrepreneur sends a signal of her type to the IVC (qualifications, experiences, etc.). It's a necessary signal but it is not sufficient to detect the quality of management and risk attitude of the entrepreneur.

iii. After screening of the project, the IVC chooses the amount of her invested capital and proposes a PSR $\Omega^{\prime}$.

iv. In the negotiation stage the IVC and entrepreneur negotiate the PSR $\Omega^{\prime}$ initially proposed by the IVC and terms of contract. This proposition depends on the entrepreneur type (which is unobservable by IVC), the remuneration scheme and their risk attitude. Note that the two parties of the contract are risk averse.

v. The IVC designs the Islamic venture capital contract including the pre agreed $\Omega$ and initial investment $I$. All the terms of the contract must be complete and clearly developed for the two parties without any uncertainty (AAOIFI, 2003). According to Islamic Law, the terms cannot be modified by any one after of the contract is signed.

vi. The entrepreneur accepts or rejects the contract considering the offers of the other IVCs, so there is interest to conclude the contract.

At $\mathrm{t}_{0}+1$ :

vii. The entrepreneur provides an effort of management which may be low $m_{L}$ or high $m_{H}$ to perform the project.

viii. Nature determines the state of the world.

ix. Their expected utilities are perfectly identified by their respective expected net payoffs. 


\section{Insert Figure 3 here}

Figure 3 shows the agency relationship between the IVC and the entrepreneur under information asymmetry. As illustrated the double arrow (a) reflects the dependence of the IVC payoff on the expected profit $\tilde{P}_{i}$ of the project because it is an expected profit share. Relation (b) explains that it exists a positive effect of the level of management on the income of the project $\tilde{P}_{i}$. This positive effect is explained by the fact that the entrepreneur is the sole responsible of the management of the project, so the higher her management quality and the stronger the expected profit of the project. Relation (c) describes the dependence of the entrepreneur payoff on the project return $\widetilde{P}_{i}$ and the quality of her management.

Our Profit-Sharing ratio model is a general equilibrium model with information asymmetry. We seek the optimal PSR that maximizes the IVC expected utility and induces the entrepreneur to participate in the Islamic venture capital contract. We specify a cardinal utility function for the IVC in order to make it more defensible for developing sensible inter personal assumptions than maximization with consumer good utility function (Bashir, Darrat and Suliman, 1993). The optimal choice of the IVC depends on the respect of her maximization's program

$$
\operatorname{Max}_{P_{i}} U_{V}\left(\tilde{\Pi}_{t_{0}+1}\right)
$$

Subject to $\quad p_{i} U_{E}\left((1-\Omega) P_{i}+g\right) \geq \underline{U_{E}}$

With $\tilde{\Pi}_{t_{0}+1}=\sum_{i} p_{i}\left(\Omega \tilde{P}_{i}+I\right)+p_{L^{-}}\left(\tilde{P}_{L^{-}}\right)$and $\underline{U_{E}}$ is the utility reserve of the entrepreneur that defines her utility of payoff if she had chosen an external option (i.e., a conventional funding) mode to finance her project. 
The entrepreneur (the agent) takes the value of her gain. Her utility function of payoff is concave. The utility function of the IVC is also concave.

$$
\begin{aligned}
& U_{E}>0 \text { and } U_{E}^{\prime \prime}<0 \\
& U_{V}^{\prime}>0 \text { and } U_{V^{\prime \prime}}<0
\end{aligned}
$$

Let $r_{V}$ denote the measurement of absolute risk aversion of the IVC and $r_{E}$ the measurement of absolute risk aversion of the entrepreneur. The optimal PSR depends on the absolute risk aversions degree of both parties. Then, the optimal Profit Sharing Ratio is

$$
\Omega^{*}=\frac{\mathrm{r}_{\mathrm{E}}}{\mathrm{r}_{\mathrm{E}}+\mathrm{r}_{\mathrm{V}}}
$$

See proof in Appendix A.

Proposition 1: The IVC has an incentive to propose the Profit Sharing Ratio $\Omega$ 'as high as possible.

\section{Insert Figure 4 here}

Figure 4 shows numerically (by using toolbox Matlab) the simultaneous impacts of the risk aversion degree of the IVC and the risk aversion degree of the entrepreneur on the optimal $\operatorname{PSR} \Omega *$.Then $\Omega *$ is not observable by either the IVC or the entrepreneur. Contrariwise, Figure 4 illustrates that the optimal PSR is more sensitive to the entrepreneur risk aversion. As a consequence, the IVC is more exposed to the risk of identifying and reaching the optimal $\Omega *$ since the entrepreneur risk aversion degree will have more important effect on $\Omega *$. Her risk aversion plays a decisive role in characterizing the optimal contract. In addition, the entrepreneur may have a rough idea about the risk aversion degree of the IVC on the market by observing her previous contracts. Then the optimal PSR would be controlled by the entrepreneur during the negotiation stage. This result stipulates that IVC has incentive to propose the ratio as high as possible such that $\Omega^{\prime} \succ \Omega *$ to ensure a margin of negotiation equal 
to $\left[\Omega^{\prime}-\Omega^{*}\right]$. This margin constitutes the adverse selection cost to the IVC since she must negotiate the PSR with the entrepreneur and will detect the entrepreneur type.

From Equation 2 of the optimal Profit Sharing Ratio, three cases are likely.

First case

$$
\begin{gathered}
\text { if } r_{E} \succ r_{V} \\
\frac{1}{2} \prec \frac{r_{E}}{r_{V}+r_{E}}=\Omega^{*} \prec \Omega^{\prime}
\end{gathered}
$$

So that, when the IVC is less risk averse than the entrepreneur, she will negotiate a PSR more than $50 \%$.The $\Omega^{*}$ increases as well. The gain of the IVC depends increasingly on the adverse selection problem. This excess over $50 \%$ corresponds to her risk premium. This result stipulates that when the entrepreneur is more risk averse than the IVC, the optimal PSR will depend on the entrepreneur risk aversion rather than the IVC risk aversion. In the negotiation stage, we argue that a high type entrepreneur $m_{H}$ could accept a high PSR near to $\Omega^{\prime}$ with $\Omega^{*} \leq \Omega^{\prime}$ since the project's profit $\tilde{P}_{i}=\tilde{P}_{H}$ will be high (because she will perform well the project) and consequently her profit share $(1-\Omega) \widetilde{P}_{i}$ will still high. So a high PSR is a sign to select the good entrepreneur). This observation implies that in the negotiation stage, the higher the risk aversion of the entrepreneur, the higher the PSR and the lower the adverse selection risk. We mean that there will be more likely that the candidate would be a high type. But a low type entrepreneur who is more risk averse than the IVC will rather negotiate a PSR near to $50 \%$ since she has not the ability to perform the project. So, the project will default $\left(\tilde{P}_{L^{-}}\right)$or generate a low profit $\left(\tilde{P}_{L^{+}}\right)$. Our argument is that the low type entrepreneur will tend to negotiate the PSR as high as possible to maximize her profit share. Therefore their risk aversion degree influences their decision in the negotiation process. Thus, during the 
negotiation stage the level of PSR may give an idea about the risk attitude and the entrepreneur type.

Second case

$$
\begin{gathered}
\text { if } \mathrm{r}_{\mathrm{E}}=\mathrm{r}_{\mathrm{V}} \\
\frac{1}{2} \approx \frac{r_{E}}{r_{V}+r_{E}}=\Omega^{*} \leq \Omega^{\prime}
\end{gathered}
$$

So that, when the IVC and the entrepreneur have the same risk aversion degree. Their risk aversions will influence their decisions in the negotiation stage. They will instead seek to negotiate an optimal PSR around50\% whatever the type of the entrepreneur. This optimal PSR maximizes their both utility functions to their respective payoffs. The result of Tag-alDin (2008) under information symmetry using quadratic utility function constructs a particular case of our general analysis. The author estimates that when the two parties have the same risk aversion, there is a perfect pure Islamic venture capital contract and stipulates that $\Omega=50 \%$ is a breakeven point of efficiency when the risk is shared fairly between the two parties. In this paper, there is not one equilibrium point. The equilibrium depends on the respective risk aversions of the entrepreneur and the IVC.

Third case

$$
\begin{gathered}
\text { if } \mathrm{r}_{\mathrm{E} \prec \mathrm{r}_{\mathrm{V}}} \\
\Omega^{*}=\frac{r_{E}}{r_{E}+r_{V}} \leq \frac{1}{2} \leq \Omega^{\prime}
\end{gathered}
$$

So that, when the IVC has a higher risk aversion degree than the entrepreneur, the optimal profit sharing ratio $\Omega^{*}$ will be below $50 \%$. The gain of the IVC will tend to become rigid. This result is due to the fact that the optimal PSR will rather depend on the risk aversion degree of the IVC since she is more risk averse than the entrepreneur. Our argument is that the IVC fears more the entrepreneur type, so she will take a larger margin of safety to limit 
her losses by motivating the entrepreneur to accept the contract. This reasoning checks the IVC's risk aversion since she prefers a low and certain profitability for a low risk that the project defaults. In addition, when the IVC is more risk averse than the entrepreneur, there are two possible cases that depend on the entrepreneur type. First, the high type entrepreneur will be less exigent than the low type entrepreneur since she knows that she is able to perform the project, so her profit share will be high whatever the PSR. Second, when the low type entrepreneur is less risk averse than the IVC (she has a low risk aversion degree), she could accept the proposed PSR $\Omega$ ' since she want to send a false signal to the IVC that she is a high one or to induce the IVC to accept her application. Then she will tend to exceed her maximum PSR $\Omega_{\text {Max }}^{L}$ that corresponds to her minimum utility (reservation utility). So, in this case the adverse selection problem is important.

Let us turn to the case where the IVC and the entrepreneur maximize respectively their utility functions and have saturate participation constraints such as

-For the IVC:

$$
\begin{gathered}
p_{i} U_{V}\left[\Omega P_{i}+I\right]=\underline{U_{V}} \\
\Omega_{\operatorname{Min}} \tilde{P}_{i}=\frac{U_{V}^{-1} \underline{\left(U_{V}\right)}}{p_{i}}-I
\end{gathered}
$$

-For the entrepreneur:

$$
\begin{aligned}
& p_{i} U_{E}\left[(1-\Omega) P_{i}+g\right]=\underline{U_{E}} \\
& \left(1-\Omega_{\text {Max }}\right) \tilde{P}_{i}=\frac{U_{E}^{-1} \underline{\left(U_{E}\right)}}{p_{i}}-g
\end{aligned}
$$

PROPOSITION 2: For $\tilde{P}_{H} \succ \tilde{P}_{L^{+}}$and $p_{H} \succ p_{L_{+}}$the minimum profit sharing ratio required to the high type entrepreneur $\Omega_{\text {Min }}^{H}$ by the IVC is lower than the minimum profit sharing ratio applied to the low type $\Omega_{\text {Min }}^{L+}$. 
The equation (3) stipulates that the minimum profit share of the IVC is the difference between her utility function that compensates her minimum utility (external option) $\underline{U_{V}}$ below which she will refuse the Islamic venture capital contract, and her invested capital $I$. Her satisfaction is reduced due to her capital contribution. From this equation, we find that the profit share of a high type entrepreneur is lower than the profit share of a low type entrepreneur such as $\Omega_{M i n}^{H} \widetilde{P}_{H} \prec \Omega_{M i n}^{L} \tilde{P}_{L^{+}}$for $p_{H} \succ p_{L^{+}}$and $\widetilde{P}_{H} \succ \widetilde{P}_{L^{+}}$. In other words the IVC fixes a minimum PSR for the high type higher than the minimum PSR for a low type. This result is explained by the fact that when the entrepreneur is a high type, the IVC will require a PSR relatively low compared to that required from a low type entrepreneur since the IVC hopes that the profit of a project performed by a high type entrepreneur will be higher. Then her profit share remains high whatever the PSR. On the other side when the entrepreneur is a low type, the IVC fixes a higher minimum PSR to maximize her profit share from a project performed by a low type entrepreneur which would generate a low profit or default. According to Kaplan (1999), fund managers argue that a higher share in the profit helps to retain and attract new talent and that top performers should be rewarded adequately.

PROPOSITION 3: For $\tilde{P}_{H} \succ \tilde{P}_{L^{+}}$and $p_{H} \succ p_{L+}$ a high type entrepreneur accepts to perform the project for a maximum profit sharing ratio $\Omega_{\text {Max }}^{H}$ higher than the maximum profit sharing ratio $\Omega_{\text {Max }}^{L}$ tolerated by a low type.

COROLLARY 1: Whatever the type of the entrepreneur is, the higher the management fee of the entrepreneur and the higher the maximum profit sharing ratio tolerated by her.

The equation (4) stipulates that the minimum profit share of the entrepreneur corresponds to her utility function that compensates her minimum utility $\underline{U_{E}}$ below which the entrepreneur does not accept the Islamic venture capital contract, reduced by her management fee $g$. In 
other words the higher the management fee of the entrepreneur, the lower her profit share and the higher the maximum PSR that she tolerates to the IVC. Our argument is that when the fixed return to the entrepreneur is important, she will be less exigent and will negotiate a high PSR because she is a risk averse entrepreneur, so she prefers certain compensation. Gompers and Lerner (1999) find in the case of classical venture capital that the risk averse fund managers are likely to prefer a more fixed fee than their variable fee where their abilities are unknown. On the other hand, for $p_{H} \succ p_{L^{+}}$we find that the high type entrepreneur has a profit share lower than the profit share of a low type entrepreneur

$$
\frac{U_{E}^{-1} \underline{\left(U_{E}\right)}}{p_{H}}-g \prec \frac{U_{E}^{-1} \underline{\left(U_{E}\right)}}{p_{L^{+}}}-g
$$

In the other words, the high type entrepreneur tolerates a maximum PSR higher than the maximum PSR tolerated by the low type entrepreneur. This result can be explained by the fact that the high type entrepreneur will perform the project better than a low type entrepreneur, and then the profit of the project will be higher. For this reason, the profit share of the high type remains high despite the magnitude of the maximum PSR tolerated to the IVC.

However, in order that the maximum PSR tolerated by the entrepreneur equals to the minimum PSR accepted by the IVC in the negotiation stage we have

$$
p_{i}\left[I+\tilde{P}_{i}\right]+p_{i} g=U_{V}^{-1}\left(\underline{U_{V}}\right)+U_{E}^{-1}\left(\underline{U_{E}}\right)
$$

The equation above implies two conditions to have an equilibrium situation between the minimum and the maximum PSR. The first condition is that the utility of the IVC that compensates exactly her minimum utility corresponds to the project value $I+\widetilde{P}_{i}$ which depends on the probability that the project succeeds. In other words the minimum satisfaction of the IVC is such as the project generates a positive profit and she can recuperate her investment capital because there is profit sharing once the profit is positive. Second condition 
is that the utility of the entrepreneur which compensates perfectly her minimum utility corresponds to her fixed management fee (which depends on the probability of success of the project). This result stipulates that the entrepreneur must have a minimum certain compensation such as management fee $p_{i} g$ to accept the contract and negotiate a maximum PSR that corresponds to the minimum PSR required by the IVC.

From the propositions 2 and 3, three are four cases to detect the entrepreneur type in the negotiation stage:

$\left.\left.-\Omega^{*} \in\right] \Omega_{M i n}^{H} ; \Omega_{\text {Min }}^{L}\right]$, there are only high type entrepreneurs. The IVC will not tolerate to a low type entrepreneur less than $\Omega_{\text {Min }}^{L}$;

$-\Omega^{*} \in\left[\Omega_{\text {Min }}^{L} ; \Omega_{\text {Max }}^{L}\right]$, there are high and low type entrepreneurs. There is adverse selection problem. This interval corresponds to the acceptance area of low and high type entrepreneurs; $\left.\left.-\Omega^{*} \in\right\rfloor \Omega_{\text {Max }}^{L} ; \Omega_{\text {Max }}^{H}\right\rfloor$, there are high type entrepreneurs. In this case, we can find also a small proportion of low type entrepreneur who has a low risk aversion;

$\left.-\Omega^{*} \in \Omega_{\text {Max }}^{H} ; \Omega^{\prime}\right]$, neither low type nor high type entrepreneur will participate in the Islamic venture contract.

The four cases are possible when the entrepreneur is risk averse and respects her acceptance area of the contract. Hence we illustrate in the next section the different points of equilibrium $\Omega^{*}$ (optimum Pareto) that depend on the risk aversion of the IVC and the risk aversion of entrepreneur, and the mutual satisfaction of their utilities.

\section{V.Discussion}

In this section we discuss our found result in the previous section by using the Edgeworth box, we will demonstrate that there are several equilibrium points that depend on the risk aversion degree of the two parties. 


\section{A. Case of two possible profits using Edgeworth box}

Assume that the project has two possible profits that depend on the type of entrepreneur.

Let $P_{i}=\left\{P_{H}, P_{L+}\right\}$ with $P_{H} \neq P_{L+}$ and $0 \leq P_{L+} \leq P_{H}$.

The IVC and the entrepreneur are rationales and risk averse. We are in the presence of a pure exchange economy. We keep the assumptions of instauration for the Edgeworth box. There are only two agents in this economy i.e. IVC and entrepreneur. In this case we can rewrite the property of efficiency (A.3) for $i=\{H, L+\}$ (since $\gamma^{*}$ is constant) as following,

$$
\gamma^{*}=\frac{\mathrm{U}_{\mathrm{V}}{ }^{\prime}\left(\Omega \widetilde{\mathrm{P}}_{\mathrm{H}}+\mathrm{I}\right)}{\mathrm{U}_{\mathrm{E}}{ }^{\prime}\left((1-\Omega) \widetilde{\mathrm{P}}_{\mathrm{H}}+\mathrm{g}\right)}=\frac{\mathrm{U}_{V}{ }^{\prime}\left(\Omega \widetilde{\mathrm{P}}_{\mathrm{L}+}+\mathrm{I}\right)}{\mathrm{U}_{\mathrm{E}}{ }^{\prime}\left((1-\Omega) \widetilde{\mathrm{P}}_{\mathrm{L}+}+\mathrm{g}\right)}
$$

From this property of efficiency there are three possible cases:

-In the first case, we suppose that the IVC is risk neutral and the entrepreneur is risk averse. In this case the utility function of the IVC is affine line and $U_{V}^{\prime}$ is constant. We have

$$
U_{E}^{\prime}\left((1-\Omega) \tilde{P}_{H}+g\right)=U_{E}^{\prime}\left((1-\Omega) \tilde{P}_{L^{+}}+g\right)=\frac{c s t}{\gamma}
$$

Then the optimal contract is such as $(1-\Omega) \tilde{P}_{i}+g$ is constant because $U_{E}^{\prime}$ is a decreasing function, i.e. the payoff to the entrepreneur is independent from the profit of the project. In this case, the IVC bears the whole risk of the project. Since there will be no risk sharing, this case cannot applied for Islamic venture capital contract. Hence the IVC must be risk averse to respect the construction of the contract and the property of efficiency.

-In the second case, if the entrepreneur was risk neutral and the IVC was risk averse, the utility function of the entrepreneur would be affine line. So $U_{E}^{\prime}$ is constant. Then we have

$$
U_{V}{ }^{\prime}\left(\Omega \tilde{P}_{H}+I\right)=U_{V}^{\prime}\left(\Omega \tilde{P}_{L^{+}}+I\right)=\frac{c s t}{\gamma}
$$


So that, when the entrepreneur is risk neutral and the IVC is risk averse, the payoff to the IVC $\Omega \widetilde{P}_{H}+I$ will be constant because $U^{\prime}{ }_{E}$ is a decreasing function and the entrepreneur bears all the risk. For the two reasons, this case is not possible for the Islamic venture capital contract where the two parties must share the risk.

-In the third case, if the entrepreneur and the IVC are risk averse, the property of efficiency is verified and the two parties share the profit and the risk of the project. For this reason, we consider only the third case for our study.

\section{Insert Figure 5 here}

Figure 5 illustrates the indifference curves of the two parties assuming that there are two possible positive outcomes $P_{H}$ and $P_{L+}$. In this context, we may assume no-saturation (we mean that the entrepreneur will always prefer to have higher utility). It will be more indifference curves. The IVC and entrepreneur have utility's functions of the same type. We obtain the curve of the Islamic venture capital contract which in the Edgeworth box connects all the points under Pareto efficient. Assume that the IVC and entrepreneur are maximizers. Each one will try to be on the indifference curve as high as possible given the indifference curve of the other. They will carry out mutually beneficial exchanges at the equilibrium point that depends on their risk aversion degree. There is an exchange in which all individuals will be more satisfied after the negotiation. From the intersection between the indifference curves of the two parties to the point $\Omega^{*}=50 \%$ where $r_{E}=r_{V}$, the equilibrium will be in the center of the Edgworth box and the PSR will be approximately $\Omega^{*} \approx 50 \%$. If $r_{E} \prec r_{V}$ the equilibrium position will be on the left side of the Edgworth box and the optimal PSR will be lower than $50 \%$. Otherwise when $r_{E} \succ r_{V}$ the equilibrium will be in the right part of the center point of the box and the two parties will tend to fixe an optimal PSR higher than 50\% to maximize their 
utilities. Hence their profit shares are done with mutual satisfaction with a less risk to select the low type candidate. We are dealing with a pure exchange economy.

\section{VI.Simulation Results}

We use CARA utility functions for both the entrepreneur and IVC to express the optimal PSR as a function of their respective risk aversion and economic viability of the project $(e=P / I)$. We then perform two numerical analyses with the optimization toolbox of Matlab to gauge the impact of these determinants on the optimal PSR.

- The impact of the economic viability of the project

Under CARA utility functions for both the entrepreneur and IVC, the optimal PSR is expressed as a function of the economic viability of the project $e$ (see Appendix B for proof):

$$
\Omega^{*}=\frac{-(1-e) \lambda_{B}+\left[(1-e)^{2} \lambda_{B}^{2}+4 \lambda_{B}\left(\lambda_{E}+\lambda_{B}\right) e\right]^{1 / 2}}{2\left(\lambda_{B}+\lambda_{E}\right) e}
$$

\section{Insert Figure 6 here}

We use three different value pairs of $\lambda_{V}$ and $\lambda_{E}$ and simulate the optimal PSR as a function of the economic viability of the project. Since, for a given $P$ and $I$, the risk aversions $r_{E}$ and $r_{V}$ are inverse functions of the parameters $\lambda_{V}$ and $\lambda_{E}$, the simulation results may be interpreted regarding the risk aversion degree of the IVC and entrepreneur. Figure 6 shows numerically that, in these three cases, the optimal PSR is a decreasing function of $e$. However the slope of $\Omega^{*}$ as a function of $e$ is higher when the entrepreneur is more risk averse than the IVC and it is lower when the IVC is more risk averse. These numerical results confirm the proposition 1 . 
- The impact of the flexibility of the invested capital and the expected profit of the project on optimal PSR

In the negotiation stage we assume that the invested capital of the IVC is flexible such that IVC can increase or decrease the level of her contribution $I$ as long as the invested capital is lower than the minimum required investment by the entrepreneur. For the numerical simulations, we use different values of the utility functions' parameters $\lambda_{V}$ and $\lambda_{E}$ in order to assess the simultaneous impact on the flexibility of the investment $I$, the expected profit $\tilde{P}$ and the risk aversion of the two parties. The simulations results are plotted in Figure 7.

\section{Insert Figure 7 here}

The graphs show that the minimum optimal PSR is expected for a weaker investment $I$ and a higher expected net profit. To explain more clearly this observation, when the investment $I$ is weak and the expected net profit is high, the IVC and entrepreneur tend to negotiate a low PSR $\Omega *$ to minimize her risk exposure. On the other hand, the entrepreneur could propose a project with high expected profit to incite the IVC to choose a lower PSR (adverse selection problem). But, comparing the two graphs in figure 7, it comes that when the risk aversion of the entrepreneur increases (decreases) and the risk aversion of the IVC decreases (increases), the optimum PSR becomes higher (lower). The results confirm our theoretical analysis.

\section{Conclusion}

This paper develops a model that defines the Profit Sharing Ratio as a screening device to avoid the adverse selection problem between the Islamic Venture Capital and the entrepreneur and to improve the profitability of a venture. To explain the Islamic venture capital contract this paper begins with designing the payoffs to the IVC and entrepreneur.

Our Profit Sharing Ratio model under adverse selection rises from the possibility of having two project profits (positive or negative) depending on the type of the entrepreneur. We define 
the agency relationship between the entrepreneur and IVC and their utility functions to maximize the IVC utility under the participation constraint of the entrepreneur. Thus the present analysis determines the optimal allocation of shares between the IVC and entrepreneur under adverse selection according to performance. The optimal PSR is expressed as a function of the absolute risk aversions of both the IVC and the entrepreneur. The analysis of our model yields the following theoretical implications:

-The model predicts that the higher the risk aversion of the entrepreneur, the lower the risk to select a bad candidate and the stronger the optimal Profit Sharing Ratio. On the other side the higher the risk aversion of the IVC the weaker the risk to select a bad entrepreneur and the lower the optimal Profit Sharing Ratio.

-We consider then that the IVC fixes a minimum profit sharing ratio to accept the Islamic venture capital contract. Thus the minimum profit sharing ratio required by the IVC is lower (higher) when the project is managed by a high (low) type entrepreneur.

-We consider also that the entrepreneur fixes a maximum profit sharing ratio to participate in the Islamic venture capital contract. Then a high type entrepreneur accepts to perform the project for a maximum profit sharing ratio higher than the maximum profit sharing ratio tolerated by a low type. In addition, we find that the higher the fixed management fee of the entrepreneur and the higher the maximum profit sharing ratio tolerated by the entrepreneur (whatever her type is).

-The numerical simulations show that when the entrepreneur is more (less) risk averse than the IVC for a high (low) invested capital $I$ and a weak (high) expected net profit the optimum negotiated PSR will be higher (lower).

In a next research a possible extension would be to enhance the gains of the IVC under an Islamic venture capital contract. The IVC can for example sale her invested capital in the form of IPO adapted to the Islamic Law or Sukuk (Islamic Obligations). This could be an 
incentive to the IVC to engage in profit sharing contracts. Another possible extension is to empirically test the determinants of the Profit Sharing Ratio. 


\section{References}

Abdalla, M. G. E. (1999), 'Partnership (Musharakah): A New Option for Financing Small Enterprises?', Arab Law Quarterly, Vol. 14, No. 3, pp. 257-267.

Abdul-Mutalib, A. L. (2000), 'Islamic Venture Capital and Private Equity: Legal Issues and Challenges'.

C:IUsers\DRMfinance\AppDatalLocal\Temp\IslamicVCandPELegalFrameworkbyAhmad Lutfi-1.pdf

Abdul-Razak, A. S. and Ismail, S. B. M. (2009), 'Practical Issues In Islamic Venture Capital', http://www.azmilaw.com/images/stories/PDF/newsletter/issue_17/17_1_Practical_Issues_in_I slamic_Venture_Capital.pdf, Issue.17, Vol. 2,

AAOIFI-Accounting and Auditing Organization for Islamic Financial Institions (2003), 'Shari'a Standards', May, Kingdom Bahrain.

Adnan, Akhyar and Muhammad (2008), 'Agency Problems in Mudarabah Financing: The Case of Shariah Rural Banks', Indonesia, In Obaidullah. "Islamic Finance for Micro And Medium Enterprises.’IRTI.

Ahmed, H. (2002), 'A Microeconomic Model Of An Islamic Bank', Islamic Development Bank: Islamic Research and Training Institue, No. 59.

Al-Jarhi, M. A. (2001), 'Enhancing Corporate Governance in Islamic Financial Institutions', paper presented to the IRTI-AAOIFI Conference on Transparency, Governance and Risk Management in Islamic Financial Institutions, held in Beirut Lebanon, March 2001.

Al-Jarhi, M. A. and Iqbal, M. (2001), Islamic Banking: FAQS, Jeddah: IRTI Occasional Paper 4.

Al-Jarhi, M. A. (2004), 'Islamic Banking and finance: Philosophical underpinnings. Islamic Banking and Finance: Fundamentals and Contemporary Issues', Islamic Research and Training Institue, Seminar Proceedings Nr. 47: 13/25, Brunei.

Bacha, O. I. (1997), 'Adopting Mudarabah Financing To Contemporary Realities: A Proposed Financing Structure', Accounting Commerce and Finance: The Islamic Perspective, Vol. 1, No.1, pp. 26-54.

Bashir, A., Darrat A. F. and Suliman M. O. (1993), 'Equity Capital, Profit Sharing Contracts, and Investment/ Theory and Evidence', Journal of Bisiness Finance and Accounting, September, pp. 639-651.

Bashir, A. (1996), 'Profit-Sharing Contracts and Investment under Asymmetric Information', Research in Middle East Economics, Vol.1, pp. 173-186.

Bashir, A. (2001), 'Profit-Sharing Contracts and Investment under Asymmetric Information', Research in Middle East Economics, 1: 173-186. 
Berger A.N., Udell G.F., (1990), 'Collateral, loan quality, and bank risk', Journal of Monetary Economics, Vol. (25), pp.21-42.

Berger, A., Molyneux. P. and Wilson., J. (2010), 'The oxford Handbook of Banking', Oxford University Press.

Boot, A., Thakor, A. and, Udell, G.F. (1991), 'Secured lending and default risk: equilibrium analysis, policy implications and empirical results', Economic Journal 101, pp. 458-472.

Burke, A. and Hanley, A. (2006), 'Bank interest margins and business startup collateral: testing for convexity', Scottish Journal of Political Economy, Vol. 53, No. 3, pp. 319-334.

Casamatta, C. (2003), 'Financing and Advising: Optimal Financial contracts with Venture Capitalists', Journal of finance, Vol. LVIII, No. 5, pp. 2059-2084.

Chapra, M. U. and Khan, T. (2000), Regulation and Supervision of Islamic Banks, Jeddah. IRTI.

Chemla, G. and De Bettignies, J. E. (2006), 'Corporate Venturing, Allocation of Talent, and Competition for Star Managers'.

Darrat, A. (1988), 'The Islamic Interest-Free Banking System: Some Empirical Evidence', Applied Economies, Vol. 20(March 1988), pp. 417-425.

Dar, H.A. and Presley, J.R. (2000), 'Lack of Profit Loss Sharing in Islamic Banking: Management and Control Imbalances', International Journal of Islamic Finanacial Services, 2(2): 3-18.

Farooq, M. O. (2007), Review of Islamic Economics, Vol. 11, Special Issue, pp. 67-88.

Galloux, M. (1999) 'The state's Responses to Private Islamic Finance Experiments in Egypt', Thunderbird International Business Review 41: 4-5 (July-October 1999), 481-500.

Gollier, C. (1999), 'The economics of Risk and Time', http://time.dufe.edu.cn/xueshushuzhai/2003613956759737.pdf, 54-61.

Haque, N. and Mirakhor, A. (1986), 'Optimal Profit-Sharing Contracts and Investment', IMF Working Paper, WP/86/12, IMF, Washington, DC.

Haque, N. U. and Mirakhor, A. (1987), 'Optimal Profit-Sharing Contracts and Investment in an Interest-Free Islamic Economy', in: Khan, M. S. and Mirakhor, A. (eds.), Theoretical Studies in Islamic Banking and Finance (Houston: Book Distribution Center).

Hasan, Z. (1985), 'Determination of Profit and Loss Sharing Ratios in Interest-Free Business Finance', Journal of Research in Islamic Economics, Jeddah, Vol. 3, No. 1, pp. 13-27.

Hasan, Z. (2008), 'Credit creation and Control: an unresolved issue in Islamic Banking', Munich Personal Repec Archive, No. 8130, (April 2008), pp. 271-284.

Hester, D. (1979), 'Customer relationships and terms of loans: evidence from a pilot survey', Journal of Money, Credit and Banking, Vol. 11, pp. 349-357. 
Karim, A. A. (2000), 'Incentive Compatible Constrains for Islamic: Banking Some Lessons From Bank Muamalat', Conference Papers, Fourth International Conference on Islamic Economics and Banking Loughborough University, UK: pp. 579-598.

Khan, W. M. (1985), 'Towards An Interest-free Economic System', Islamic economic series, the Islamic foundation, Leicester, UK.

Khan, M. S. (1986), 'Islamic Interest-Free Banking: A Theoretical Analysis', IMF, Staff Papers, Vol. 33 (March 1986), pp. 1-27.

Khan, M. S. and Mirakhor, Abbas (1987), Theoretical Studies in Islamic Banking and Finance, Houston, USA, The Institute of Research and Islamic Studies.

Lean, J. and Tucker, J. (2001) 'Information Asymmetry, Small Firm Finance and the Role of Government', Journal of Finance and Management in Public Services, Vol. 1, pp. 43-60.

Leeth J.D., Scott J.A., (1989), 'The incidence of secured debt: evidence from the small business community', Journal of Financial and Quantitative Analysis, Vol. (24), pp. 379-394.

Leland, H. and Pyle, H. (1977), 'Informational Asymmetries, Financial Structure, and Financial Intermediation', Journal of Finance, Vol. 32, No.2, pp. 371-387.

Machauer, A. and Weber, M. (1998), 'Bank behavior based on internal credit ratings of borrowers', Journal of Banking and Finance, Vol. 22, pp. 1355-1383.

Manove, M. and Padilla, A. J. (1999), 'Banking (Conservatively) with Optimists', RAND Journal of Economics, Vol. 30, pp. 324-350.

Manove, M., Padilla, A. J. and Pagano, M. (2001), 'Collateral versus project screening: a model of lazy banks', RAND Journal of Economics, Vol. 32, No. 4, pp. 726-744.

Mills, P. and Presley, J. R. (1998), 'Islamic Finance: Theory and Practice', (London: Macmillan).

Neinhaus, V. (1983), 'Profitability of Islamic PLS Banks Competing with Interest Banks: Problems and Prospects', Journal of Research in Islamic Economics, Vol. 1 (Summer 1983), pp. 37-47.

Pryor, F. L. (1985), 'The Islamic Economic System', Journal of Comparative Economics, Vol. 9, pp. 197-223.

Sarker, M. A. A. (1999), 'Islamic Business Contracts, Agency Problem and the Theory of the Islamic Firm', International Journal of Islamic Financial Services, Vol. 1, No. 2. 
Saurina, J., and C. Trucharte. (2004). 'The Impact of Basel II on Lending to Small- and Medium-Sized Firms: A Regulatory Policy Assessment Based on Spanish Credit Register Data', Journal of Financial Services Research, Vol. 26, No, 2, pp. 121-44.

Shaikh, S. A. (2011), 'A Critical Analysis of Mudarabah \& A New Approach to Equity Financing in Islamic Finance’, Journal of Islamic Banking \& Finance, No. 19697.

Stiglitz, J. E. and Weiss, A. (1981), 'Credit Rationing in Markets with Imperfect Information', The American Economic Review, Vol. 71, Issue. 3 (June), pp. 393-410.

Sugema, I. Bakhtiar, T. and Effendi, J. (2010), 'Interest versus Profit-Loss Sharing Credit Contract: Effciency and Welfare Implications', International Research Journal of Finance and Economics, Issue. 45, pp. 58-67.

Tag El-Din, S. I. (2008), 'Income Ratio, Risk-Sharing, and the Optimality of Mudarabah', JKAU: Islamic Econ., Vol. 21, No. 2, pp. 37-59.

Vickrey, W. (1961), "Counter speculation and Competitive Sealed Tenders." Journal of Finance, Vol. 16 (1), pp. 8-37.

Wette, H. C. (1983), 'Collateral in Credit Rationing in Markets with Imperfect Information: Note', The American Economic Review, Vol. 73 (3), pp. 442-45.

Williamson, S.D. (1986), 'Costly monitoring, financial intermediation, and equilibrium credit rationing', Journal of Monetary Economics, Vol. 18, pp. 159-179. 


\section{Figure 1: Payoff to IVC at the liquidation time}

This figure is composed of three graphs. The graph (1.1) plots the payoff to the IVC as function of $P$ in the case of Islamic venture capital. The graph (1.2) illustrates the payoff to the IVC as function of $R$ in the case of IVC. For the three graphs, we assume that the invested capital is not flexible. The project requires an investment amount $I=100$. The Profit-Sharing ratio $\Omega=30 \%$.

(1.1) Net Income of the project $(P)$

(1.2) Project Value (R)

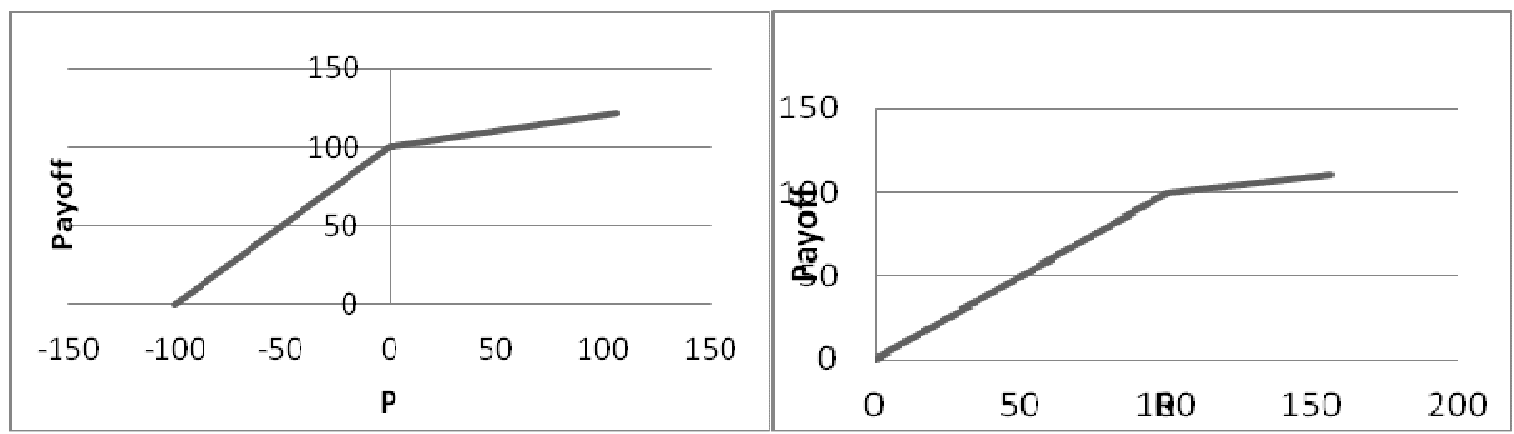

\section{Figure2: Payoff to Entrepreneur as function of $P$ At the liquidation time}

This figure is composed of three graphs. The graph (2.1) plots the payoff to the entrepreneur as function of $P$ in the case of IVC. The graph (2.2) illustrates the payoff to the entrepreneur as function of $R$ in the case of IVC. For the three graphs, we assume that the invested capital is not flexible. The project requires an investment amount $I=100$. The Profit-Sharing ratio is fixed at $60, g=0$ and $\Omega=30 \%$.

\section{(2.1) Net Income of the project (P)}

(2.2) Project Value (R)
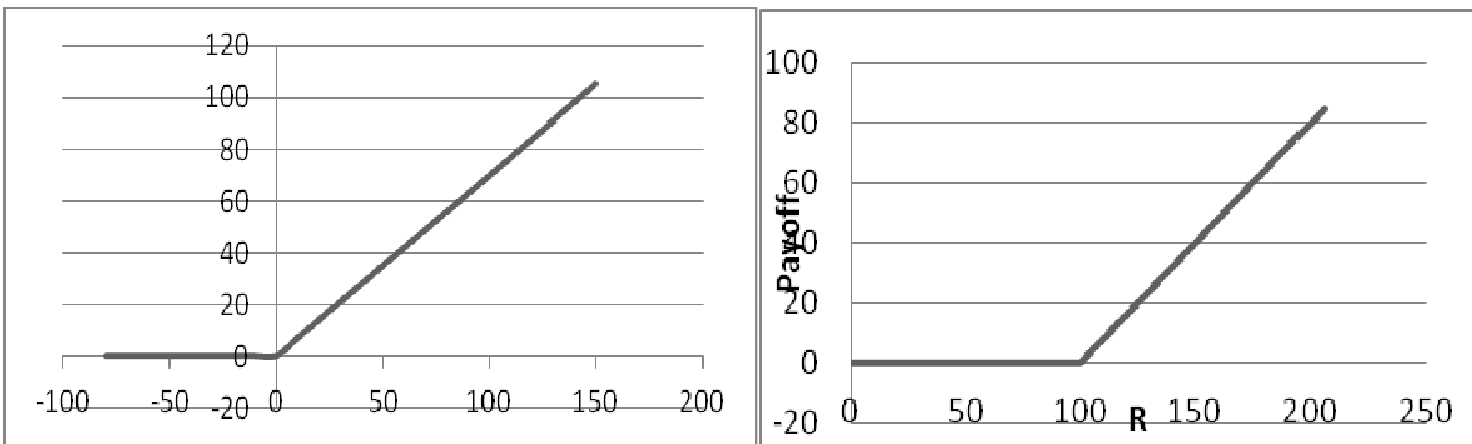


\section{Figure 3. Agency relationship between the IVC and the entrepreneur}

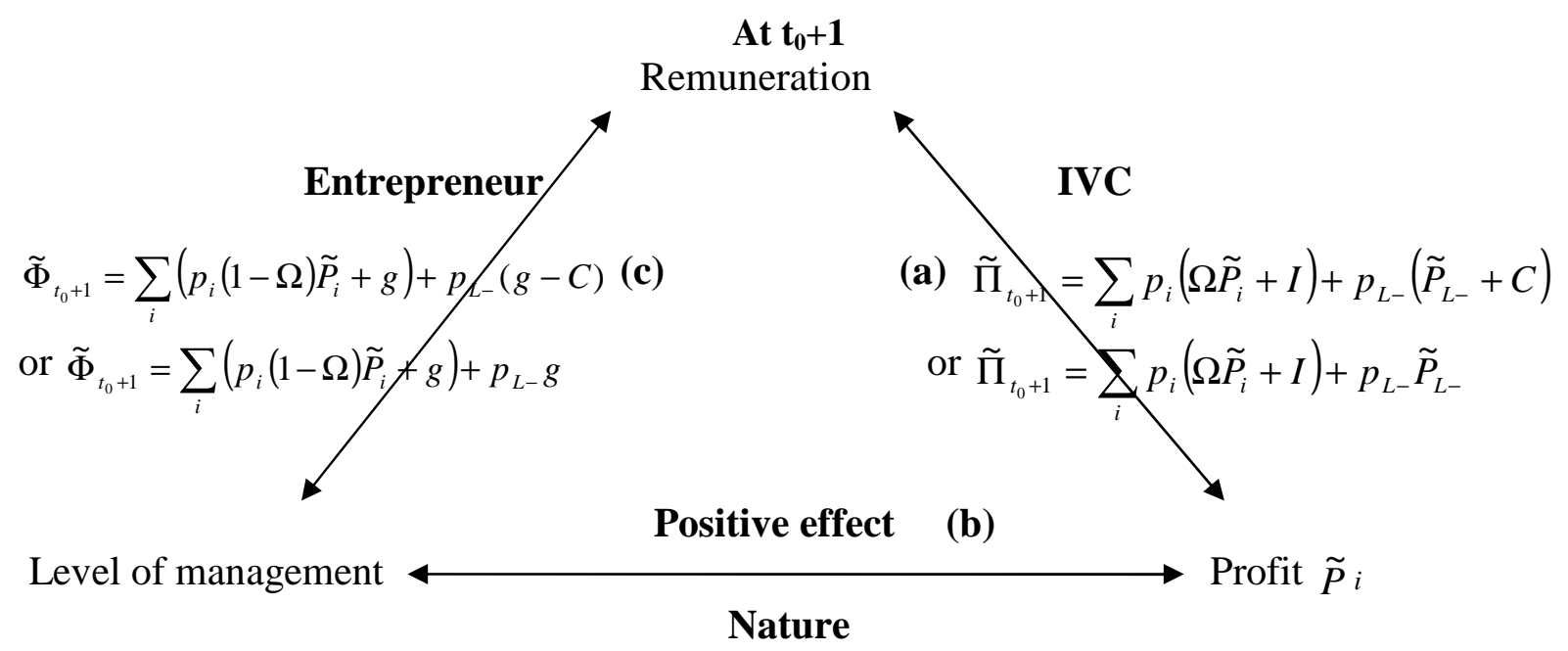

Figure 4. Optimal PSR as function of the IVC risk aversion and the risk aversion entrepreneur

This figure plots the variation of the optimal PSR, at the stage of negotiation, as function of the risk aversion of the entrepreneur $\left(r_{E}\right)$ and the risk aversion of the IVC $\left(r_{V}\right)$. The figure is computed using the following parameters values: $0.5 \leq r_{E} \leq 4$ and $0.5 \leq r_{V} \leq 4$. We choose the interval of value because we estimate that a degree of risk aversion beyond 4 implies that the risk premium will not be realistic (Gollier, 1999).

Optimal PSR

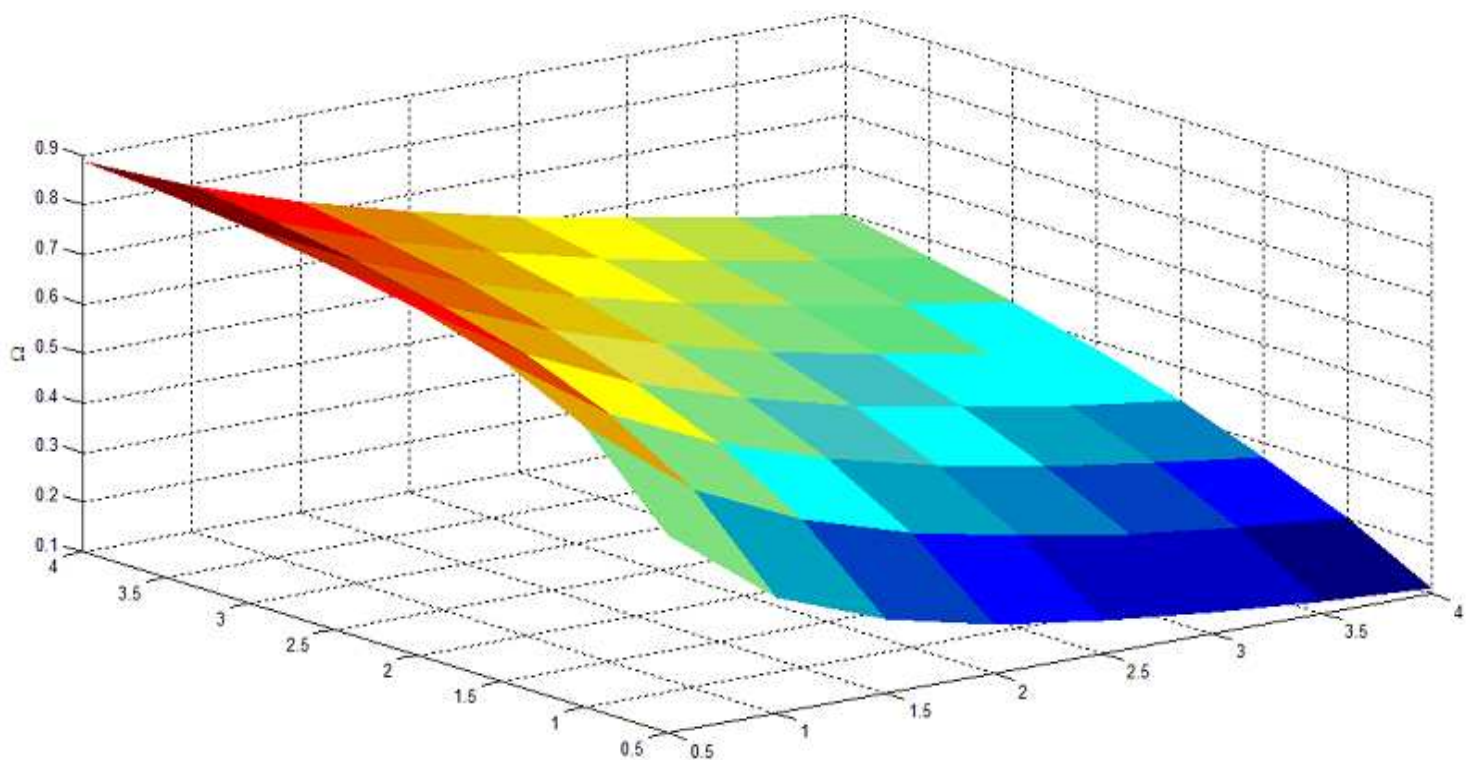

Risk aversion of the entrepreneur $\left(\mathrm{r}_{\mathrm{E}}\right)$

Risk aversion of the IVC $\left(\mathrm{r}_{\mathrm{V}}\right)$ 
Figure 5. Box of Edgeworth

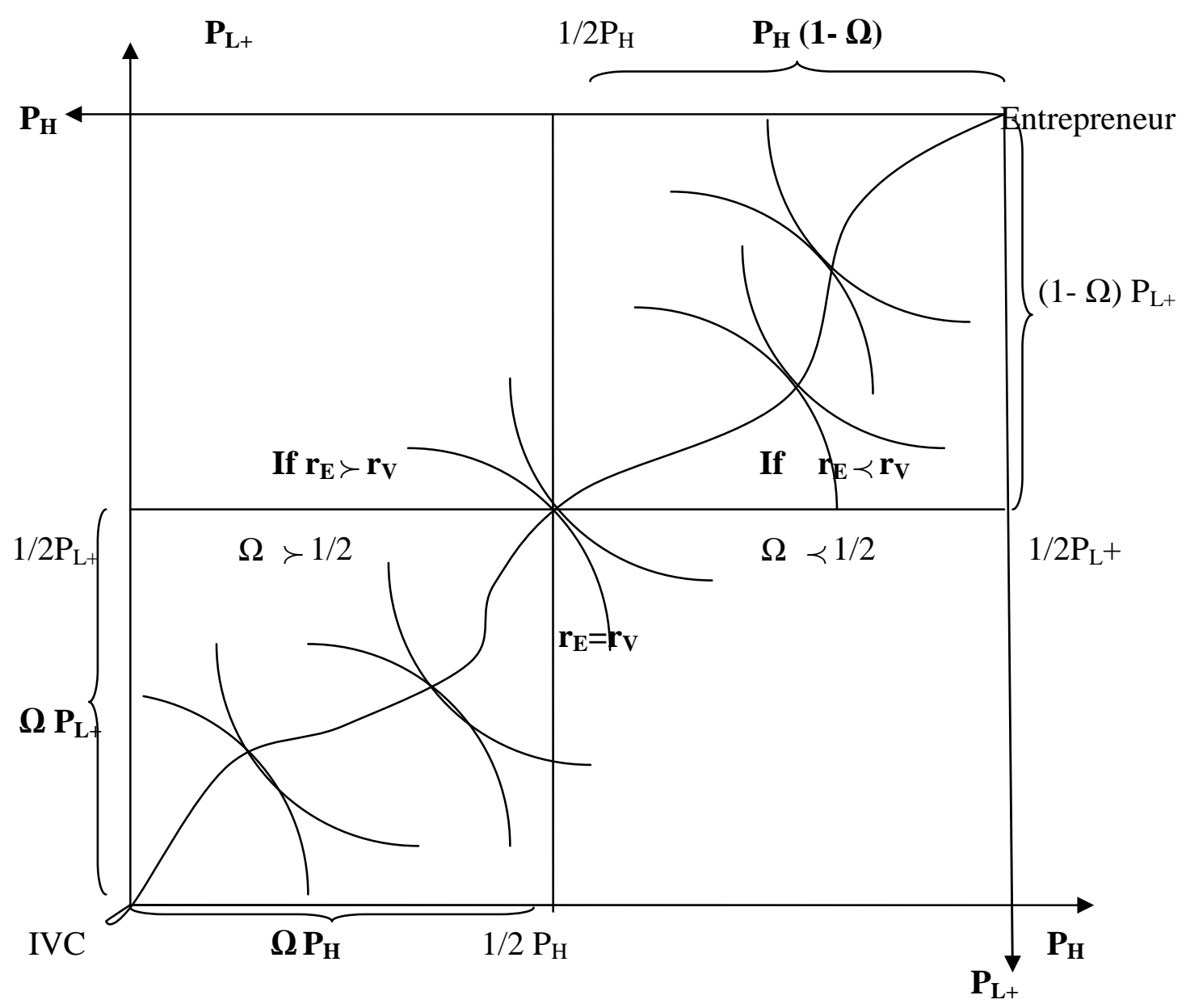




\section{Figure 6. Optimal PSR as function of economic viability}

This figure illustrates three curves plotting the optimal PSR $\Omega *$ as function of the economic viability $(e)$ of the project. The figure is computing using the following parameters values: $0 \leq e \leq 0.5$.

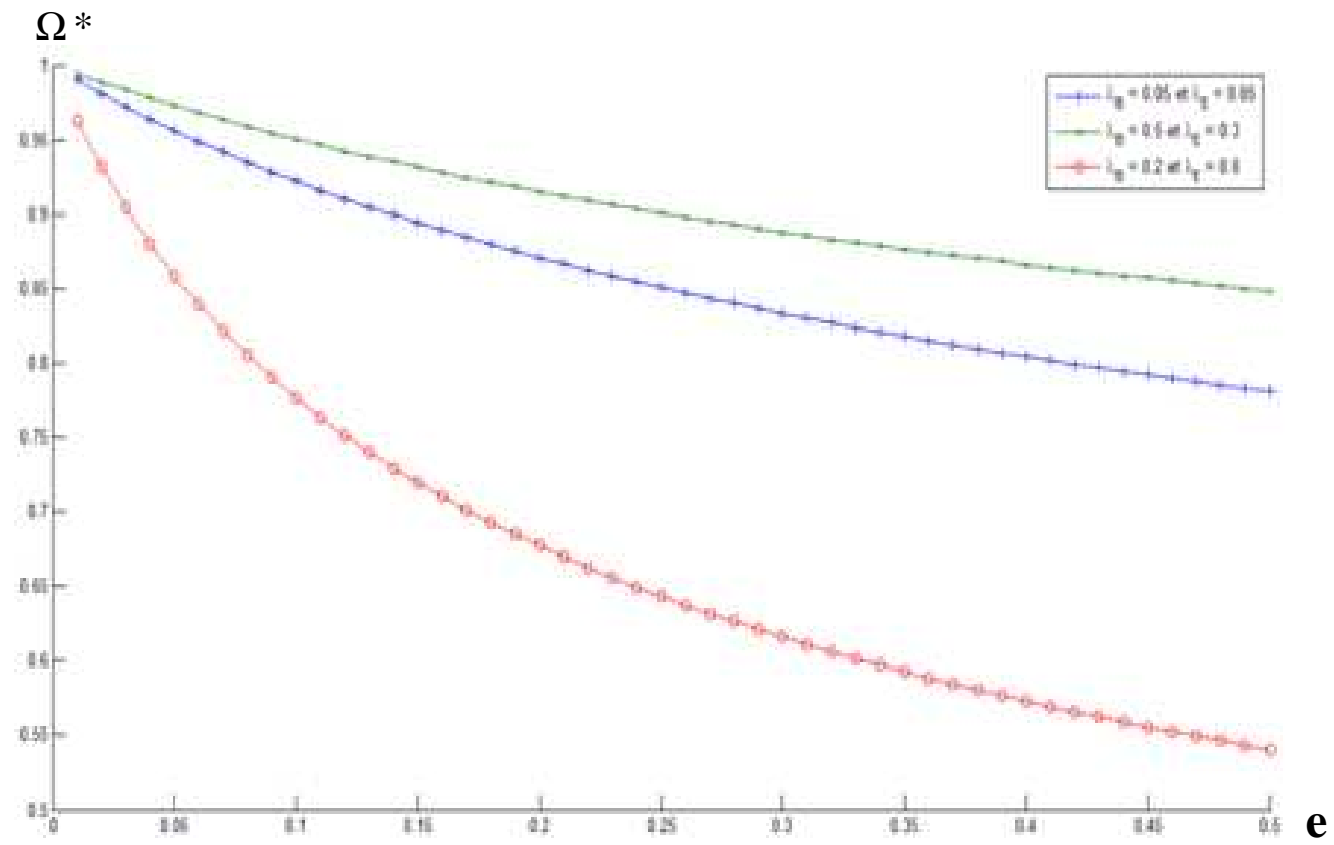




\section{Figure 7. The optimal PSR as function of the income of the project and the invested capital}

This figure is composed of two graphs. The graphs plot the Impact of the variation of the invested capital $I$ and the variation of income of the project on the optimal PSR at $t=0$. The graphs are computed using the following parameters value: $10 \leq I \leq 100$ and $0 \leq P \leq 50$. The first graph is illustrated as function of $\lambda_{E}=0.3$ and $\lambda_{V}=0.5$. The second graph is computed using: $\lambda_{E}=0.8$ and $\lambda_{V}=0.2$.

Optimal PSR

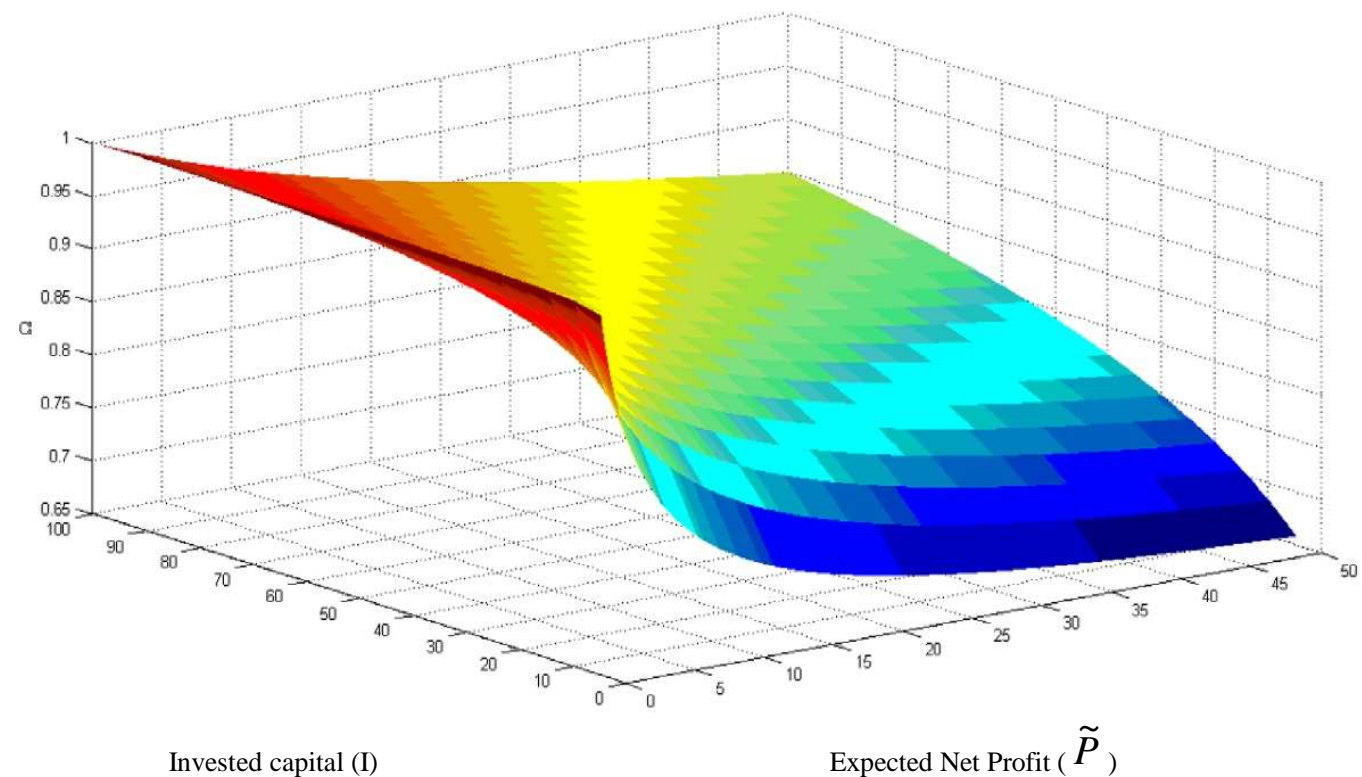

Optimal PSR

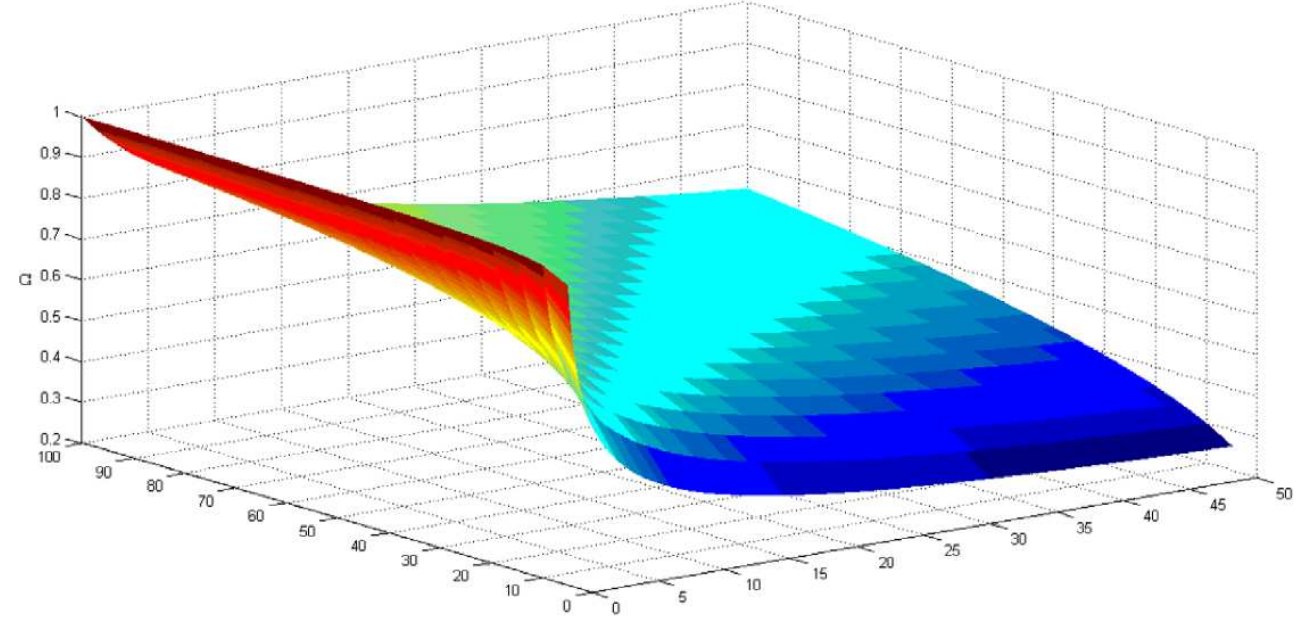

Invested capital (I)

Expected Net Profit ( $\tilde{P}_{\text {) }}$ 


\section{APPENDIX A}

\section{Proof of Equation (2)}

Given the fixed value of $\Omega$ the optimal contract curve for the IVC and the E is defined in terms of the two levels of profit $\left(P_{H} \succ 0\right.$ and $\left.P_{L+} \succ 0\right)$ that maximize the bank's utility function subject to any level of the E's utility function. Hence, the participation constraint of the bank can be defined as:

$$
p_{i} U_{E}\left((1-\Omega) \tilde{P}_{i}+g\right) \geq \underline{U}_{\underline{E}}
$$

Where $p_{i} U_{E}\left((1-\Omega) \tilde{P}_{i}+g\right)$ represents the estimate of a gain in random utility, $v\left(m_{i}\right)$ uncertain effort and $\underline{U}$ is external option. Hence, the constrained utility function can be defined symmetrically for the bank and the $\mathrm{E}$ is:

$$
L\left(P_{i}, \gamma\right)=p_{i} . U_{V}\left(\Omega \tilde{P}_{i}+I\right)+\gamma\left[p_{i} U_{E}\left((1-\Omega) \tilde{P}_{i}+g\right)-\underline{U}_{E}\right]
$$

Where, $\gamma$ is constant Lagrange multiplier and $\gamma \geq 0$, then, at equilibrium, the first order conditions of constrained maximization over the profit sharing ratio are:

$$
\begin{aligned}
& \frac{d L}{d P_{i}}=p_{i}{ }^{*} \cdot \Omega^{*} U_{V}{ }^{*}+\gamma^{*} p_{i}(1-\Omega) U_{E}{ }^{\prime}=0 \\
& \frac{d L}{d \gamma}=p_{i} U_{E}\left((1-\Omega) \tilde{P}_{i}+g\right)-\underline{U}_{E}=0 \text { (suppose that the participation }
\end{aligned}
$$

condition is saturate)

From (A.1), we have,

$$
\begin{aligned}
& (1-\Omega) U_{E}{ }^{\prime} \gamma^{*}=-\Omega * U_{V}{ }^{*}{ }^{*} \\
& \gamma^{*}=\frac{-\Omega U_{\mathrm{V}}{ }^{\prime}}{(1-\Omega) \mathrm{U}_{\mathrm{E}}{ }^{\prime}}
\end{aligned}
$$

Thus, the parameter $\gamma^{*}$ represents a ratio between the utilities derived from the IVC and the entrepreneur multiplied by the ratio between the profit sharing ratios of the two parties of the contract. This is what we call the Lagrange multiplier such as the property of efficiency. Thus, we can say that the efficiency of an Islamic venture capital contract depends on a mutual sharing of marginal utility (respectively of the bank and the entrepreneur) on a profit sharing ratio $\Omega$.

Differentiating (A.3) with respect to $\tilde{P}_{i}$

$$
(1-\Omega)^{2} U_{E}{ }^{\prime \prime} \gamma^{*}=-\Omega * 2 U_{V}{ }^{*} *
$$

The ratio between (A.2) and (A.3),

$$
\begin{gathered}
\frac{\mathrm{U}_{\mathrm{E}}{ }^{\prime}}{(1-\Omega) \mathrm{U}_{\mathrm{E}}{ }^{\prime \prime}}=\frac{\mathrm{U}_{\mathrm{V}}{ }^{\prime}}{\Omega \mathrm{U}_{\mathrm{V}}{ }^{\prime \prime}} \\
\Omega=\frac{\mathrm{U}_{\mathrm{E}}{ }^{\prime \prime} \mathrm{U}_{\mathrm{V}}{ }^{\prime}}{\mathrm{U}_{\mathrm{V}}{ }^{\prime \prime} \mathrm{U}_{\mathrm{E}}{ }^{\prime}+\mathrm{U}_{\mathrm{E}}{ }^{\prime \prime} \mathrm{U}_{\mathrm{V}}{ }^{\prime}}
\end{gathered}
$$

Yet, $U_{V}{ }^{\prime \prime} U_{E} " \neq 0$ (because the two parties are risk averse) 


\section{APPENDIX B}

\section{Proof of Equation (6)}

Assuming particular CARA utility function for the equilibrium position drived in the section

IV, let

$$
U(w)=\frac{1}{\lambda-1} w^{1-\frac{1}{\lambda}}
$$

With $\mathrm{w}$ is the wealth of the agent and $1 / \lambda$ is her risk aversion $(\lambda \succ 0$ and $\lambda \neq 1)$

We use this utility function because the risk aversion of the agent is a decreasing function of her wealth. When $\mathrm{r}_{\mathrm{B}}$ raises, the PSR $\Omega *$ decreases and consequently her wealth $w_{V}=\Omega \tilde{P}+I$ decreases. And when $\mathrm{r}_{\mathrm{E}}$ increases, the PSR $\Omega *$ increases and consequently her wealth $w_{E}=(1-$ $\Omega) P$ decreases. Hence, let

Fort the IVC: $U\left(\Omega \tilde{P}_{i}+I\right)=\frac{1}{\lambda_{V}-1}\left(\Omega \tilde{P}_{i}+I\right)^{1-\frac{1}{\lambda_{V}}}$

Differencing equation (B.1) with respect to $P$, we have:

And,

$$
U^{\prime}\left(w_{V}\right)=\frac{\Omega}{\lambda_{V}}\left[\Omega \tilde{P}_{i}+I\right]^{\frac{-1}{\lambda_{V}}}
$$

We have, $r_{V}=\frac{-U^{\prime \prime}\left(w_{V}\right)}{U^{\prime}\left(w_{V}\right)}=\frac{\Omega}{\lambda_{V}\left[\Omega \widetilde{P}_{i}+I\right]}$

$$
U^{\prime \prime}\left(w_{V}\right)=\frac{-\Omega^{2}}{\lambda_{V}{ }^{2}}[\Omega \tilde{P}+I]^{\frac{-1}{\lambda_{V}}-1}
$$

Now, for the entrepreneur, we have: $U\left((1-\Omega) \tilde{P}_{i}\right)=\frac{1}{\lambda_{E}-1}\left((1-\Omega) \tilde{P}_{i}\right)^{1-\frac{1}{\lambda_{E}}}$

Differencing equation (B.3) with respect to $P$, we have:

$$
\begin{gathered}
U^{\prime}\left(w_{E}\right)=\frac{(1-\Omega)}{\lambda_{E}}[(1-\Omega) \tilde{P}]^{-1} \lambda_{E} \\
\left.U^{\prime \prime}\left(w_{E}\right)=\frac{-(1-\Omega)^{2}}{\lambda_{E}}[(1-\Omega) \tilde{P}]^{-1}\right]_{E}^{-1}
\end{gathered}
$$

We have, $r_{E}=\frac{-U^{\prime \prime}\left(w_{E}\right)}{U^{\prime}\left(w_{E}\right)}=\frac{1}{\lambda_{E} \widetilde{P}}$

Now we remplace (B.2) and (B.4) in $\Omega^{*}=\frac{r_{E}}{r_{E}+r_{V}}$

We find, $\quad \Omega^{*}=\frac{-[I-\tilde{P}] \lambda_{V}+\left[(I-\tilde{P})^{2} \lambda_{V}^{2}+4 \lambda_{V} I\left(\lambda_{V}+\lambda_{E}\right) \tilde{P}\right]^{1 / 2}}{2\left[\lambda_{E}+\lambda_{V}\right] \tilde{P}}$

If we divide (B.5) by $I^{2}$, we find the optimal PSR as function of the economic viability of the Project $\tilde{e}=\frac{\tilde{P}}{I}$ :

$$
\Omega^{*}=\frac{-(1-\tilde{e}) \lambda_{V}+\left[(1-\tilde{e})^{2} \lambda_{V}^{2}+4 \lambda_{V}\left(\lambda_{E}+\lambda_{V}\right) \tilde{e}\right]^{1 / 2}}{2\left(\lambda_{V}+\lambda_{E}\right) \tilde{e}}
$$

